\author{
Beata Bigaj-Zwonek \\ http://orcid.org/0000-0003-1316-375X \\ Jesuit University Ignatianum in Krakow \\ beata.bigaj@ignatianum.edu.pl \\ DOI: $10.35765 /$ pk.2020.2801.12
}

\title{
Religious Motifs in Polish Contemporary Art Using the Crucifixion: An Outline of the Problem
}

\section{ABS TRAC T}

Sacred motifs have a long tradition in art and ample figurative representation. They have been present in the visual arts for numerous reasons, from the need to identify faith to artistic expression based on commonly-known truths and stories saturated with meaning. In the art of the twentieth century, Christian motifs were often an excuse to speak about the world, its threats and fears, and the human condition. Polish artists frequently availed themselves of religious symbols and systems in the post-war era, and during the political transformation of the 1980s, they became a way to articulate uncertainty, expectation, and hope for change. Today, the religious trope is a pretext for artistic commentary on religion, social problems, and internal issues of the creators themselves. The article explores the causes and the nature of artistic practice rooted in Christian iconography in Polish contemporary art, with a particular emphasis on the motif of the crucifixion.

KEYWORD S : crucifixion, iconography, contemporary art

\section{STRESZCZENIE}

Motyw religijny w polskiej sztuce współczesnej na przykładzie ukrzyżowania. Zarys problemu

Motywy sakralne mają w sztuce długą tradycję i bogatą reprezentację figuralną. W plastyce były obecne $\mathrm{z}$ różnych pobudek, od potrzeby identyfikacji wiary po możliwość artystycznej ekspresji bazującej na powszechnie znanych prawdach i historiach nasyconych treścią. W sztuce XX wieku motyw chrześcijański bywał wielokrotnie pretekstem do wypowiedzi o świecie, o jego zagrożeniach, lękach, o kondycji człowieka. W Polsce po znaki i układy religijne sięgano w sztuce niejednokrotnie w czasach powojennych, a w okresie przełomu politycznego lat 80 . stały się one sposobem wyrażania niepewności oraz oczekiwania i nadziei na zmiany. Także dzisiaj motyw religijny stanowi pretekst do różnorodnych wypowiedzi artystycznych, które dotyczą religii, problemów społecznych oraz wewnętrznych przeżyć samych twórców. Artykuł 
zarysowuje powody i charakter przekazów plastycznych opierających się na ikonografii chrześcijańskiej w polskiej sztuce współczesnej, ze szczególnym uwzględnieniem motywu ukrzyżowania.

SŁOWA KLUCZE: ukrzyżowanie, ikonografia, sztuka współczesna

It is not about stylization or aesthetization, modern kitsch or the illegible gibberish of form jumbled up with content. This is about what we leave behind for those who will judge us for our work. They will probably see our story in our art. They will infer our faith from our paintings and sculptures. (Rodziński, 2005, p. 62)

Contemporary artists use religious motifs fairly often to express themselves in both sacred and profane spaces. Reasons for incorporating sacred iconography in artistic concepts may be spiritual, e.g., the desire to exercise a larger point about life with reference to an evocative and universally resonant symbol. There are also more prosaic motives, such as breaking into public awareness and making an easy debut in the world of art through controversy. In Polish contemporary art, the problematics of religious symbolism (mainly Christian) seems even more interesting because it has often served as a sign of independence and hope in post-war history. It was particularly important in the seventies and eighties, when it was perceived as a message of shared identity and aspirations. The dynamic changes after 1989, however, shook the emancipatory context of the religious trope and, in many contemporary artworks, it is rather linked to criticism of the Church than to its liberating lineage.

The changing approach to drawing on Christian symbols stems from various factors. We can include among them the contemporary widespread access to information about religion, faith, and the Church, which evokes the need to discuss them with the help of easily identifiable signs. This need often involves the use of radical means of expression, the assumption being that a controversial message has a greater impact. Contemporary changes in defining one's own freedom and civic liberty against the background of a strong tradition of the Church in Poland are not without significance here: if they are expressed in a casual treatment of religious themes, this happens with the understanding that religion is important for most Poles, and therefore the artistic power of Christian emblems is also significant. ${ }^{1}$ After all, the cause of controversial art alluding to religious

1 Regardless of the assessment of the idea and the works of art themselves, it is worth mentioning the social discontent and media discussions around Dorota Nieznalska's Pasja [Passion] or Maurizio Cattelan's La Nona Ora. 
symbolism may not necessarily be related to issues of faith, but rather to a sort of natural rebellion: the younger generation, growing up in the era of global media and the values that they propagate, rebelling against the older generation, clinging to tradition and rituals.

Often, the problematic presence of a religious symbol in Polish contemporary art should be read in the context of the history of the world, the country, and the church, but also through the lenses of possible meanings which are hidden within the religious motif. Such a motif may be used for spiritual reasons or in a social context, or in the tradition of art. Biblical scenes or truths of the Christian faith were, after all, the heart of many works of art, and thanks to the Church's powerful role in history in general, the Christian symbol is recognizable to most viewers. As a carrier of meanings understood by a general audience, sacred motifs have become an attractive means of expression in art, but it is worth remembering that it also has the potential to moderate reactions to art. In the eighteenth century, Sir Joshua Reynolds, the painter, the first director of the Royal Academy in London, urged students to choose a religious theme for their paintings:

Strictly speaking, indeed, no subject can be of universal, hardly can it be of general, concern; but, there are events and characters so popularly known in those countries where our Art is in request that they may be considered as sufficiently general for all our purposes.... Such too are the capital subjects of Scripture history, which, beside their general notoriety, become venerable by their connection with our religion.... There must be something either in the action or in the object in which men are universally concerned, and which powerfully strikes upon the public sympathy. (Reynolds, 1771, pp. 47-48)

The preference for certain subjects in art based on their potential to captivate the interest of viewers - and thus, the chance to cultivate empathyhas been stressed since the dawn of culture. And so, for example, the question of passion as a subject worth taking up in art perfectly fits with the statements of Aristotle, who, in Poetics, presents suffering as a prominent constituent of the tragedy. He defines pathos, which he also calls one of the means of persuasion (serving to move the listeners), a "destructive or painful action, such as visible deaths, torments, woundings, and other things of that kind" (Aristotle, ca. 335 B.C.E./1987, p. 33). These two quotes can be summarized in the opinion of the French academic theorist André Félibien, who wrote about the need for a lofty subject in L'Idée du Peintre Parfait, as cited in Tatarkiewicz: 
Painting requires something grand, stimulating and extraordinary, something which can surprise, please, and instruct; that thing is what is called grand taste: it is this which makes ordinary things beautiful, and beautiful things sublime and marvelous. For in painting, grand taste, sublimity, and marvelousness are one and the same thing. (1970, p. 377)

Today, when an artist seems to be solely responsible for their art, before himself/herself and the audience, in a time when art patronage and commissioning no longer influences artists' creativity (mostly), using a religious symbol should have another, preferably valid, reason. This reason may be a commentary on various matters conveyed by means of a sacred motif; it may also be a reference to the centuries-old tradition of representation in painting, sculpture, or graphics. But an artist may also engage with sacred iconography because of the most obvious desire of the artist to confront: firstly oneself, by taking up a subject which has been thematized in art for generations, and secondly, this grand topic, which carries a lot of meaning. Importantly, there is also an opportunity for catharsis, which may occur when studying a motif with a great semantic capacity.

One of the most frequently used sacred iconographic motifs is the crucifixion. Artists utilize the symbol of the cross or the motif of the crucifixion because it invites many interpretations and is easily recognizable. In the twentieth century, Expressionist painters, some of whose more dramatic works revolved around the despair and grief of war, were particularly willing to deploy this symbolism. In his White Crucifixion from 1938, Marc Chagall depicted Christ dressed in a tallit and surrounded by scenes of pogroms and persecution of Jews. Thus, Christ's suffering is linked with the suffering of the Jewish people through the motif of the crucifixion (Bażanowska, n.d.). In a lithograph from 1945, Oskar Kokoschka portrayed Christ tearing himself away from the cross with one arm to offer himself to hungry children. The transverse shoulder of the cross bears the inscription: "In Memory of the Children of Europe Who Have to Die of Cold and Hunger this Xmas." 2 The 1923 work, Jesus With a Gas Mask, by George Grosz, depicts Christ holding a cross in his hands and wearing military boots and a gas mask. The inscription to this print says, "Maul halten und weiter dienen" ["Shut up and obey"], which probably refers to stigmatizing the bourgeoisie, who, by cultivating the religion of peace, downplayed the signals of danger and failed to prepare themselves and the nation for war (Jacob, n.d.; Vallen, 2003).

2 See https://www.albrightknox.org/artworks/19463-memory-children-europe-who-have-die-cold-and-hunger-xmas (Retrieved August 29, 2018). 
In later times, the crucifixion remained a capacious literary medium, also capable of expressing the situation of twentieth-century man, entangled in various social mechanisms, human weaknesses, and passions. This motif was taken up by both believers and non-believers. It became an "attractive" means of communication for "engaged art"-globally (Neofigurative art) and domestically (e.g., the Wprost group) — as it responded to the needs of the trends that focused on the evocative and expressive power of images. The religious motif, as a traditional symbol which can be understood by a general audience, was consistent with the idea delineated by Zbylut Grzywacz, co-creator of the Wprost group:

In order to make the experience of a painting intense, we must often refer to a symbol; let it be reclaimed again and again, let it be more than just a trigger that recalls the story of myth. A statement that boils down to a recollection of archetypal ideas is just as threatened by lifelessness as a painting prematurely locked into an aesthetic formula. (Gorządek, 2006)

Engaged art which used the sacred motif understood its potential, independent of any professed faith. One of the most famous figurative painters of 20th century, Francis Bacon-who often revisited the motif of the cross and the crucifixion-said,

You may say it's a curious thing for a nonreligious person to take the Crucifixion, but I don't think that that has anything to do with it.... I haven't found another subject so far that has been as helpful for covering certain areas of human feeling and behavior.... [In painting the Crucifixion] you're working then about your own feelings and sensations, really. You might say it's almost nearer to a self-portrait. You are working on all sorts of very private feelings about behavior and about the way life is. (Sylvester, 1987, pp. 44-46)

However, in Polish history, the symbol of the cross, as well as other religious symbols, with a particular emphasis on themes related to the Passion, became an expression of social feelings during martial law. The independent cultural exhibitions held at that time were, in many respects, bound up with the religious sphere, for instance, because of the venues, which were both private spaces, but often churches as well. In an interview with Agnieszka Gralińska-Toborek (2012), Zbylut Grzywacz recalled, "There was a boycott of official exhibitions, so we participated in church shows." And to the question about the participants of these exhibitions, he answered, "As an unbeliever, I attended masses and sometimes did so with tears in my eyes. 'Let us offer one another a sign of peace' then sounded like a sign of the Solidarity movement, and not necessarily a sign 
of reconciliation with the Lord" (Gralińska-Toborek, 2012). The artists, looking for a language understandable to a broad audience, used patterns that were both clear to everyone and particularly significant in the Polish context, as they were connected with Polish tradition, mentality, and religiosity. In addition, they had already been used in art to communicate the difficult subject of war, as exemplified by the work of Antoni Rząsa or Władysław Hasior. Then and during the Solidarity struggle, the symbol of the cross and the figure of the crucified Christ were used to portray the complicated situation of the people and the country. The cross was synonymous with undeserved and cruel torture inflicted on the innocent, but it was also a symbol of a temporary condition that would end in a triumph of justice (Rogozińska, 2002b). Paintings from the martial law period expressed the artists' anger and their rebellion and disagreement with the times, while concurrently delivering a message to the nation, bringing comfort, and sometimes simply evoking a feeling of community. The Symbol of the Cross exhibition held at the Church of Divine Mercy in Warsaw in 1983 is an example of combining both religious and social themes during this period. It featured a lot of interesting works of art in which the cross opened the way towards other — not solely religious - considerations. Jerzy Kalina, creator of the Last Supper installation displayed at the exhibition, reminisces:

The Symbol of the Cross exhibition was a very notable meeting of many artists... The idea became more crystallized during the "retreat seminars" for which we gathered in Laski. There, we met with Father Salij, for example, who told us a lot about the cross: he not only spoke about its extensive symbolism, but we also had very long, lively discussions at the intersection between the sacred and the profane. (Kalina, 2006)

Paintings, sculptures, and drawings employing the symbol of the cross and the motif of the crucified Christ have been created by such artists as Władysław Paciak, Leszek Sobocki, Andrzej Bielawski, Eugeniusz Mucha, Maciej Bieniasz, and Jerzy Duda-Gracz. Critics and commentators on the political situation and on culture in Poland have noticed the pervasive presence of religious symbols and references to sacred iconography during the Polish transformation and just before it. At that time, it aroused curiosity and understanding, but also bewilderment. Today, however, it can be evaluated differently. Danuta Wróblewska, in an interview with Wiesława Wierzychowska, noted that

we just had to return to some imagery, which means we had to use some iconography that would be completely different than the previous one, but one that was commonly and unambiguously felt .... The foreigners 
thought that we went insane then and lapsed into bigotry. They could not understand that if you break with one convention, you must find another. The only thing that could fully counter a language destitute of meaning was Christian themes. (Gralińska-Toborek, 2005, p. 192)

Sacred motifs, which were frequently explored at that time, served as a starting point for both good artwork and some that would not necessarily go down in art history books, although as Stanisław Rodziński observes,

it was in those years that the artists saw the need to discover religious motifs; "cornered by history," they saw and discovered them when the escape from the religious universe was obvious. If these inspirations were genuine, they resulted in a many valuable works. If religious iconography was a symbol, perhaps rather a symbol of political anger or an opportunistic ploy, it resulted in art, which we will browse like old postcards and posters, as mere documents of the fight for independence. (2005, p. 51)

In times of independent culture, in many cases, there was no doubt that religious symbols were meant to allude to contemporary Polish history. In other cases, it was more personal. Often, both attitudes converged in one work of art. One example is the paintings of Edward Dwurnik from his Cross series ${ }^{3}$. In his work from the late '70s, the figure of the crucified Savior either united a community lost in the "only right" system or was depicted as an outright victim of the communist regime. In Christ Outside the City from 1979, the cross marks the place of prayer meetings. A group of people keeping watch by the cross, kneeling and praying, find themselves surrounded by outlined silhouettes of militia officers. In turn, in the painting entitled Christ on a Car from 1979, a publicly humiliated Christ is driven through the streets of the city, assisted by militia and soldiers. Naked, hung on a cross made of a frame, stripped of human dignity, he is displayed in this demeaning ride in a militia or military vehicle with an open top. Christ is also represented as an innocent, undeserved victim in the paintings of Dwurnik from the '90s. In Christ in the Square from 1991, the dark silhouette of a man hung on a cross occupies the central part of the painting. The cross, with a special shape (an amalgam between St. Andrew's cross and a double cross), is set on a flowered square of something like a small-town marketplace. Onlookers have gathered by the floral decoration to watch Christ like a monument or some local attraction. "For Edward Dwurnik, the starting point in painting the Passion is not faith in Jesus God-Man, but a meditation of himself, a common man on

3 See http://www.dwurnik.pl/cykle.php? ID = 21 (Retrieved August 29, 2018). 
existential suffering," Dominik Łuszczek sums up this aspect of the artist's work. As he goes on to explain, "this meditation inspired by the philosophy of Joseph Beuys has a christomorphic character: I am Christ, I am suffering" (1998, p. 54).

Łuszczek's insight also encapsulates the art of Zbylut Grzywacz, which often incorporated religious motifs, and the symbol of the cross appears in his work on various themes, such as in the Abandoned series, referring to the story of Mary Magdalene (Rogozińska, 2010). ${ }^{4}$ This series, dating from the 1970s, was mostly based on the trope of a woman embracing/ lying at the foot of a cross/pole/man (arranging his arms as if he was hanging on a cross). In some paintings, a dressed/naked woman is on an empty street or indifferent pedestrians pass by her. Sometimes she has accessories, like a bag with banknotes and food vouchers. She is desperate, despairing. She is embracing the cross/non-cross, as if she was seeking help, hope, or forgiveness. Perhaps she is holding the cross/crucified Christ to stay with her? "However, only in Abandoned VII are the efforts of contemporary Magdalene successful. She undergoes transformation and starts to resemble the body of the Savior" (Rogozińska, 2010, p. 113). The scene of the crucifixion is also linked to paintings under the joint title Stretched. Stretched (1972-1973), Stretched II (1974), and Stretched III (1975-1981) depict a figure holding a banner as if the human silhouette was stretched between its spars. In Stretched II, the hero of the painting, with his back to us, ripped his torso out of the exertion of stretching the shaft, and revealed his insides, from which the spine "was removed," in the artist's words, "like from a filleted fish" (Rogozińska, 2010, p. 109). In Stretched III, the banner oozes drops of blood. "The martyrdom of the Stretched," explains Renata Rogozińska, "does not emerge ... as a model of Christian bravery and holiness ... on the contrary, it is futile, completely useless, and, in addition, deprived of a higher purpose" (2010, p. 113).

We can mention many interesting works of art which were created in this period of a kind of suspension, but also of development in Polish culture, and which allow for broad interpretations and a prompt reflection on history, in particular the history of Poland, and on oneself. Let our last example of an artwork drawing on religious symbols be Eugeniusz Get-Stankiewicz's Do it yourself from 1977, illustrating a different use of the cross trope. It consists of elements suggesting a DIY project: canvas, a simple wooden cross in the center, a small figure of the crucified Christ

4 See also Rogozińska, R., Zbylut Grzywacz, Brunon Tode, Jerzy Stajuda. Niebo w btocie [Zbylut Grzywacz, Brunon Tode, Jerzy Stajuda: Sky in Mud]. In W strone Golgoty. Inspiracje pasyjne w sztuce polskiej w latach 1970-1999 [Towards Golgotha: Passion inspirations in Polish art, 19701999]. Poznań: Księgarnia Św. Wojciecha. 
on the right side of the cross, and a hammer and three nails on the left. At the bottom, the artist wrote the title: "do it yourself."

Decades after the creation of the above-mentioned art, the overtones and character of artistic projects which include an association with religion and which address social issues is often quite different. The controversial exhibition, Irreligion: Non-sacred morphology in Polish art, presented at the Atelier 340 Museum in Brussels in 2001 and 2002, seems to echo these modern changes. This exhibition, protested by church institutions and Catholic circles, among others, seems to be an expression of today's need to answer the question about the presence of the Church and God in the everyday human sphere, in social life, in Poland, and beyond. And although undoubtedly some of its exhibits may have aroused objections, they voice the difficulty of finding oneself in a world in which certain values have lost their stable foundation and stopped regulating everyday life. The exhibition included works with various references to contemporary problems of religion, the Church and church institutions, e.g., referring to the issue of displaying faith in the media and politics-Adam Rzepecki's image of the Mother of God with a moustache (Kuryłek, 2013, p. 15) or kitsch in sacred art and simulation of faith-Robert Rumas's religious figures immersed in colored liquid (Sienkiewicz, n.d.; Ziarkiewicz, 1995, pp. 60-66). ${ }^{5}$ The title, Irreligion, which is connected to Colin Campbell's theory of non-religiousness (Campbell, 1983), was to be understood, according to the words of the exhibition curator, Kazimierz Piotrowski, as follows:

Irreligion, or more appropriately an irreligious attitude, is an attitude towards religion which asks questions about the foundations of religious doctrine that is the cultural bonds of the individual more than contesting the existence of the objects of faith. (Szyłak, n.d.)

Among the exhibits were artworks using the symbol of the cross. One of them is Grzegorz Klaman's installation, which consists of a human brain inserted in a cross-shaped glass container, from the Emblems series. According to the artist, the Emblems "provoke discussion about the place of faith and the open body" (Interview, 2012). On another occasion, as cited in Sabor (2003), he stated that he presents the body (parts), which "while losing its symbolic meaning, becomes subordinated to medical knowledge, which is a form of exercising control over it. It is either a shell

5 I think that in the context of this exhibition and the controversial artistic projects using religious symbols, it is worth suggesting the reading of S. Rodziński's Czy artyście wszystko wolno? [Is the Artist Free?] in Rodziński, 2005. 
onto which meanings are being inscribed or meat which is being processed." Another example from the exhibition which employs the symbol of the cross is Leszek Knaflewski's Couple from 1990, showing two roots topped off with crosses "like a couple of lovers" (also resembling two wavy swords), arranged on a white shroud/sheet (Wasilewski, 2014). As Marek Wasilewski (2014) writes, "It was a poetic and multivalent question about the boundaries of privacy and intimacy crossed by religious institutions.”

Recalling the various projects that were exhibited in Brussels, it is worth pondering on the words of the curator, who, in defense of the idea of the show, claimed that although this art may be challenging to interpret, it is an expression of the significance of religion in Poland (Nie chciałem wojny, 2001). When asked about the motivation of the artists presenting their work in Brussels, he noted, "[the artists] have shown a Polish phenomenon because they still deal with religion, while their colleagues in the West do not do that anymore. Even when they provoke, it means that religion is still important for them. Our culture has not yet become secularized."

In this context, it is worth recalling another exhibition which explored the aspects of faith and religion, albeit in a different way. In 2013, the project The Dangerous Liaisons: Contemporary Polish Video Art in the Face of Faith, Religion, and the Church was presented at the Center for Contemporary Art at Ujazdowski Castle. The exhibition presented the works of Ada Karczmarczyk, Kobas Laksa, Leszek Knaflewski, Katarzyna Kozyra, Karol Radziszewski, and others. The curators, while reiterating that the invited artists shared "an awareness of the impact of education in a Catholic culture on all areas of life," also pointed out that, although

the influence of the Church and religion has been subjected to very sharp and critical analysis in art for years ... it seems that today, along with the progressing secularization of society, criticism is often replaced by dispassionate observation, bearing the characteristics of a documentary or of journalism. (O.pl, 2013)

At least some of the exhibition artworks_-often calling on the language of satire and pastiche_comment on a certain, often stereotypical, image of the Church and religion that emerges from media coverage, as well as from the superficial proclamations of some believers. The artwork based on the conventions of documentary film, which ostensibly cast the artist aside, challenging the viewer to interpret the images in their own way, have a similar commentary character (however, it should be remembered that it is always the artist who delineates the boundaries of interpretation). Exhibits such as Ada Kaczmarczyk's film based on the convention of 
a music video presenting footage from a mass, Katarzyna Kozyra's documentary Looking for Jesus, or Kobas Laksa's record of a project of scattered flowers in Spycifestum, may also intrigue the audience because they enter the multifaceted issues of faith/religion/the Church using a non-traditional language of forms from the medium of film, which is relevant to our times, and its various possibilities (the music video or the documentary) (Plewicka, n.d.). It induces the viewer to find their own interpretation, but also poses the danger of a shallow level of appeal due to the attractiveness of the picture and the associations with easily digestible television productions. ${ }^{6}$

A socially or politically engaged discourse which refers to religious symbols is one-but not the only-manifestation of contemporary interest in Christian iconography. The abovementioned examples of art incorporating the symbol of the cross and the crucifixion may or may not contain elements of the artist's spiritual experience. However, the majority of artists often use religious themes for themselves: the quintessence of their work is then the confrontation with the theme and with the sacrum inherent within it. This approach is valid today, but it is also connected with centuries-old tradition, and with the works that artists of previous generations left behind, works about which we are certain or we believe that they were created for the authors themselves and in relation to their faith. Stanisław Rodziński's crucifixions have a very personal, intimate, focused quality; they refer to his own thoughts, and at the same time, they are set in a metaphorical Polish landscape. Figures of Christ, Mary Magdalene, Mary-immersed in darkness or emerging in an intense color from a dark background, often scratched out in a layer of thick paint, rough, shiny, or, conversely, matteseem to be the result of a long, difficult path, seeking the truth and discarding the irrelevant. Under the guise of harsh succinctness, they hide unnamable feelings. Even if there is a figure known from the history of Poland or the Polish Church—such as John Paul II or Jerzy Popiełuszko—standing near the cross, the artist's paintings still seem to be a story about his

6 It is also worth taking note of other interesting exhibitions touching on the sacred sphere in Polish contemporary art, such as the Sacrum Art Triennial held at the Municipal Art Gallery in Częstochowa (see The 6th Sacrum Art Triennial 2006: Problem Exhibition - In the Face of Evil, Municipal Art Gallery in Częstochowa, 2006 and Community - Compassion - Empathy: The 9th Art Triennial of Sacrum Częstochowa 2016, Municipal Art Gallery in Częstochowa, Częstochowa 2016); exhibitions of the Gallery of Contemporary Sacred Art at Praczki House in Kielce (http://www. dompraczki.pl); and the exhibition Towards Sacrum - art/non-art at Galeria Gardzienice in the Monastery of the Dominican Church in Lublin from 2012 (http://www.kul.pl/wobec-sacrum-sztuka-nie-sztuka-wystawa,art_37108,1338411600,6.html). In this context, it is also worth seeing works from the exhibition at the Warsaw Zachęta entitled In God We Trust from 2013 and articles devoted to it (official event website: http://zacheta.art.pl/pl/wystawy/in-god-we-trust). 
own attitude to certain outlooks and destinies than an interpretation of the nation's history. In an interview with Marek Karwala, Stanisław Rodziński talked about the difficulty of confronting a grand subject:

Quite early, when I was still studying, I started painting religious paintings that were an attempt at my own interpretation of faith. Such attempts are always extremely disconcerting, because both the painter himself and the viewer may arrive at the belief that everything has already been said in this respect. How does one paint the crucifixion or the pieta, when it was already done brilliantly many years ago? Well, it seems to me that I was then subconsciously convinced I would like to do it again, but in my own way. This is a dangerous task and I have learned that lesson many times. (Karwala, n.d.)

The author's own interpretation of an iconographic motif, or perhaps more — of the religious, human, historical sense of this motif — was/is the goal for artists such as Jerzy Nowosielski, Krzysztof Bucki, Jacek Waltoś, Andrzej Okińczyc, Jacek Sempoliński, Stanisław Kulon, Stanisław Cukier, Stanisław Białogłowicz, Grzegorz Bednarski, Tadeusz Boruta, Antoni Cygan, Adam Brincken, Jerzy Fober, Grzegorz Stachańczyk, Kinga Nowak, Magdalena Siejko, and many others (Rogozińska, 2002). In each of their attempts, the reason for "dealing with" the sacred theme may be/ is different. Małgorzata Kitowska-Łysiak (2004), writing about Grzegorz Bednarski's paintings inspired by the works of Valdés de Leala, notes, "[Bednarski] had to face both pressure and the impression of tradition ... he had to, as it were, reflect them in the mirror of his own existential and religious experiences, and in the mirror of his artistic aspirations and skills." 7 Jerzy Fober, in turn, explains:

I am looking for this important cause, i.e., the subject, the essence of the problem that I want to convey. For example, The Resurrection of Lazarus: it was not the story from two thousand years ago or illustrating it that was important for me, but the issue of death and liberation from it. Crossing to the other side and then returning from it and living with this awareness. Such a thing is not going to happen to any of us because no one has been on the other side. This problem is universal, contemporary, and relevant to every person, so it is always important for me to find this reason. (Giełdoń-Paszek, 2009)

On the other hand, in an interview entitled My Meeting with the Crucified, Jacek Sempoliński, the author of dynamic, expressive crucifixions, had this to say on the subject:

7 See also Rogozińska (2002a). 
It engrossed me completely. Finally, the great religious art of the past spoke to me-the works of Giotto, Michelangelo, El Greco, Titian-as my chance.... I decided that in the whole drama of my personal life, I had found the only permanent foothold. This has a theological connotation, but I care less about those. Probably, the main reason for my conviction is the dual nature of Jesus, who was both God and man. Because I can't stop being human, this person in the Holy Trinity is my greatest support. $\mathrm{He}$ is for me. God the Father is a more abstract order of being. Here is reality. (Górnicka-Zdziech, 2011)

These few statements of artists taking up the sacred motif which are cited above outline the essence of this personal confrontation with a grand subject. The final effect of encounters with the Christian symbol can be as varied as artistic paths, from minimalist styles to elaborate compositions which are rich in meaning, references, and metaphors. Personal struggles with Christian motifs as saturated as the crucifixion, provided they are the basis for one's own thoughts and inner conflicts, offer a chance to touch the sacred, which is not so much connected to the form of the motif, but to entering its content, much deeper than could be inferred from the arrangement of the figures on the surface. After all, as Georg Wilhelm Friedrich Hegel wrote about Passion themes in Lectures on Aesthetics,

for here the subject is provided precisely by God in the opposite of his triumph, in the abasement of his limitless power and wisdom.... It is God who suffers insofar as he is man, confined within this specific limitation, and so his grief does not appear as merely human grief over a human fate; on the contrary, this is an awesome suffering, the feeling of an infinite negativity, but in a human person as his personal feeling. (Hegel, 1835/n.d.)

An artist who engages with a big theme takes it on for its sake as much as for himself/herself, and the image becomes a personal image. We can deduce only from the artists' comments cited here that someone who incorporates a symbol that is important to the public must resolve the dilemma of whether their concept fits the chosen symbol. It is then important to be able to ask oneself whether a given message corresponds to a symbolism as powerful as sacred iconography? Do some ideas not convey trivial, banal content under the guise of a weighty theme? The artist therefore faces this existential question, which should probably be asked at the birth of each piece: "What for?" If the answer makes sense, there is a chance to avoid the effect which plagues a great deal of quasi-critical, quasi-engaged, quasideclarative artworks, where a flimsy idea is sometimes illustrated with too powerful a symbol that is incompatible with the content. 
However, at the same time, perhaps art in the face of a sacred symbol need not always be so prudent and faultless by design? For many, a symbol such as a cross alone grants the right to error, on the condition that there are important premises for its use in the work. An important feature of such art can then be the value of the work and the arduous struggle: with oneself, one's faith, God, the sacred, tradition, history, or with the awareness of the many meanings of the motif. Often, a very personal statement in art is bound up with a process that can be as important as the final result. And the trace of this process, which mostly remains on canvas or stone, can ultimately be as important to someone as it was for the creator.

Let me finish this outline of religious symbols in Polish contemporary art with the words of the artist whose statement begins this article. Stanisław Rodziński, in My Sketchbook, sharing with the reader his thoughts on the essence of art—great, religious, sacred—or the creativity of his friends, conveyed two thoughts that, in my opinion, summarize well the difficult topic of the sacred symbol and contemporary references to it. The first thought is that "important works are those that, while preserving the necessary comprehensibility, respect the audience, but also do not release them from thinking and from feeling more complex phenomena" (Rodziński, 2005). And the second thought, which, I think, fits with each of the motives for using the sacred motif mentioned in this paper, is as follows:

The point is not to paint religious images. The point is also not that the refusal to paint should make the artist worse or show a lack of spirit. Rather, when undertaking the effort to create paintings that are a token of our faith, and often a sign of our indifference towards God, to do it truly, within our limits, our broken words and thoughts, which are often the prayer of the modern man. (Rodziński, 2005, p. 52)

\section{REFERENCES}

Aristotle. (1987). Poetics (Stephen Halliwell, Trans.). Chapel Hill: University of North Carolina Press. (Original work published ca. 335 B.C.E.)

Bażanowska, E. (n.d.) Motyw ukrzyżowania w twórczości Marca Chagalla na podstawie wybranych obrazów [The motif of the crucifixion in the works of Marc Chagall based on selected paintings]. Retrieved July 12, 2018, from http://diec.mazurska.luteranie.pl/pl/biuletyn/MTE_2006_08_38.htm

Campbell, C. (1983). Propozycja konceptualizacji pojęcia „irreligia” i ,irreligijność" [An approach to the conceptualization of irreligion and irreligiosity]. In F. Adamski (Ed.), Socjologia religii. Wybór tekstów. [Sociology of religion: Selected essays]. Krakow: Wydawnictwo Apostolstwa Modlitwy. 
Giełdoń-Paszek, A. (2009). [Program for the exhibition, Jerzy Fober - na obraz i podobieństwo]. Orońsko.

Gorządek, E. (2006, December). Grupa Wprost [The Wprost Group]. Culture. pl. http://culture.pl/pl/tworca/grupa-wprost

Gorządek, E. (2011, April). Leszek Knaflewski. Culture.pl. http://culture.pl/ $\mathrm{pl} /$ tworca/leszek-knaflewski

Górnicka-Zdziech, I. (2011). Moje spotkanie z Ukrzyżowanym. wywiad z Jackiem Semolinskim [My meeting with the crucified: Interview with Jacek Sempolinski]. http://www.deon.pl/religia/duchowosc-i-wiara/zycie-i-wiara/art,271,moje-spotkanie-z-ukrzyzowanym,strona,1.html

Gralińska-Toborek, A. (2005). Plastyka w Kościele w latach 1981-1989: trwałe przymierze czy epizod? [Fine arts in the Church, 1981-1989: A lasting covenant or an episode?]. Pamięć i Sprawiedliwość Vol. 4, No. 1 (7).

Gralińska-Toborek, A. (2012, January 5). Wycieczka do obozu wroga. Rozmowa ze Zbylutem Grzywaczem [Trip to the enemy camp: Interview with Zbylut Grzywacz]. http://maj77.meissner.pl/pl/wydarzenia/27/Wycieczka -do-obozu-wroga-rozmowa

Hegel, G.W.F. (n.d.). Lectures on Aesthetics. https://www.marxists.org/reference/archive/hegel/works/ae/part3-section3.htm (Original work published ca. 1835)

[Interview with Grzegorz Klaman]. (2012). Retrieved August 11, 2018 from http://www.mediations.pl/2012/biennale/artysci/210-grzegorz-klaman.

Jacob, R. (n.d.). George Grosz. Künstlerische Zerrissenheitmit Realitätssinn. Retrieved July 12, 2016 from http://sunday-news.wider-des-vergessens. $\mathrm{de} / \mathrm{p} \mathrm{p}=6564$

Kalina, J. (2006, November). Przeciw ztu i przemocy. Fragmenty rozmowy z Anna Szynwelska [Against evil and violence: Excerpts from a conversation with Anna Szynwelska]. http://www.artin.gda.pl/text/text-pl-29.php

Karwala, M. (n.d.) Imperatyw wartości. Rozmowa z profesorem Stanistawem Rodzinskim, rektorem Akademii Sztuk Pięknych w Krakowie [The imperative of values: Interview with Professor Stanistaw Rodzinski, rector of the Academy of Fine Arts in Krakow]. Retrieved June 23, 2016 from http://www. up.krakow.pl/konspekt/konspekt7/gosc7.html

Kitowska-Łysiak, M. (2004). Powolne czytanie malowideł [Slow reading of paintings]. In Grzegorz Bednarski. Galeria u Jezuitów [Grzegorz Bednarski: The gallery at the Jesuits]. Poznań.

Kuryłek, D. (2013). Naprawdę nie jestem nihilistą. Wybrane aspekty twórczości Adama Rzepeckiego w latach 1979-1989 [I'm really not a nihilist: Selected aspects of the works of Adam Rzepecki, 1979-1989]. In K. Radziszewski (Ed.), A. Rzepecki. Preferuje bardziej zrzute niż kulture [A. Rzepecki: I prefer Pitch In to Culture]. Nowy Sącz: Sokol. 
Łuszczek, D.K. (1998). Inspiracje religijne w polskim malarstwie i grafice 19811991 [Religious inspirations in Polish painting and graphic art, 1981-1991]. Społeczny Komitet im. Ojca Dominika Łuszczka.

Nie chciatem wojny! mówi komisarz "Irreligia" [interview with Kazimierz Piotrowski]. (2001, December 5). Ekai.pl. https://ekai.pl/nie-chcialem-wojny -mowi-komisarz-irreligia

O.pl (2013, October 3). http://news.o.pl/2013/10/03/niebezpieczne-zwiazki -csw-zamek-ujazdowski-warszawa/\#/

Plewicka, M. (n.d.). „Niebezpieczne zwiazki” z cyklu „Video Room” - nowa wystawa w Centrum Sztuki Wspótczesnej w Warszawie ["Dangerous Liaisons" from the "Video Room" series: A new exhibition at the Center for Contemporary Art in Warsaw]. Retrieved July 12, 2018 from http://wo24.pl/ niebezpieczne-zwiazki-z-cyklu-video-room-nowa-wystawa-w-centrum-sztuki-wspolczesnej-w/

Reynolds, J. (1771). Seven Discourses on Art: Delivered to the Students of the Royal Academy on the Distribution of the Prizes, December 10, 1771. http:// www.authorama.com/seven-discourses-on-art-6.html

Rodziński, S. (2005). Mój szkicownik [My Sketchbook]. Krakow-Lublin: Gaudium.

Rogozińska, R. (2002). W strone Golgoty. Inspiracje pasyjne w sztuce polskiej w latach 1970-1999 [Towards Golgotha: Passion inspirations in Polish art, 1970-1999]. Krakow: Muzeum Narodowe w Krakowie.

Rogozińska, R. (2002a). Grzegorz Bednarski. Pawana na belke i gwoździe [Grzegorz Bednarski: Pavane with Beam and Nails]. In R. Rogozińska, W strone Golgoty. Inspiracje pasyjne w sztuce polskiej w latach 1970-1999 [Towards Golgotha: Passion inspirations in Polish art, 1970-1999]. Księgarnia Św. Wojciecha.

Rogozińska, R. (2002b). Strzec się obiektywizacji? Spór o wizje ukrzyżowania [Beware of objectivity? Dispute Over the Vision of the Crucifixion] In R. Rogozińska, W strone Golgoty. Inspiracje pasyjne w sztuce polskiej w latach 1970-1999 [Towards Golgotha: Passion inspirations in Polish art, 1970-1999]. Księgarnia Św. Wojciecha.

Rogozińska, R., Zbylut Grzywacz, Brunon Tode, Jerzy Stajuda. Niebo w btocie [Zbylut Grzywacz, Brunon Tode, Jerzy Stajuda: Sky in Mud]. In W strone Golgoty. Inspiracje pasyjne w sztuce polskiej w latach 1970-1999 [Towards Golgotha: Passion inspirations in Polish art, 1970-1999]. Poznań: Księgarnia Św. Wojciecha.

Rogozińska, R. (2010). Zdrutowane niebo. Motywy pasyjne w twórczości Zbyluta Grzywacza [Wiry sky: Passion motifs in the oeuvre of Zbylut Grzywacz]. In J. Boniecka (Ed.), Artysta wobec siebie i spoteczeństwa twórczośc Zbyluta Grzywacza i jej konteksty [The artist towards himself and society: The work of Zbylut Grzywacz and its contexts]. Krakow: Muzeum Narodowe w Krakowie. 
Sabor, A. (2003, March 23). Bezpieczny bunt [Safe rebellion]. Tygodnik Powszechny, No. 12 (2802). http://www.tygodnik.com.pl/dodatek-ks/06/ sabor.html

Sienkiewicz, K. (n.d.) Robert Rumas. Retrieved July 11, 1016 from http://culture.pl/pl/tworca/robert-rumas.

Sylvester, D. (1987). The brutality of fact: Interviews with Francis Bacon. London: Thames and Hudson.

Szyłak, A. (n.d.). Święci buntownicy. "Irreligia" na wtasne oczy - relacja z Brukseli Anety Szytak [Holy rebels: Irreligion with my own eyes - A report from Brussels]. Retrieved July 11, 2018 from http://raster.art.pl/prezentacje/irreligia/irreligia.htm

Tatarkiewicz, W. (1970). In J. Harrell, C. Barrett, \& D. Petsch (Eds.), History of aesthetics. London-New York: Continuum.

Vallen, M. (2003, December 25). Christ in a gas mask! https://www.indymedia. org.uk/en/2003/12/283162.html

Wasilewski, M. (2014, September 7). Leszek Knaflewski (1960-2014). http:// czaskultury.pl/czytanki/leszek-knaflewski-2

Ziarkiewicz, R. (1995). Nie mam na celu zbawienia świata. Wywiad Ryszarda Ziarkiewicza z Robertem Rumasem [I'm not trying to save the world: Ryszard Ziarkiewicz's interview with Robert Rumas]. Magazyn Sztuki, No. 6-7, pp. 60-66.

Beata Bigaj-Zwonek-Dr. hab., painter, professor at the Ignatianum Academy in Krakow. Her research interests include art and culture, in particular the issues of artistic creation and the creative process. 
